\title{
A DIDACTICAL APPROACH PROPOSITION IN ENVIRONMENTAL EDUCATION IN A BRAZILIAN HIGHER EDUCATION CONTEXT
}

Rodolfo Antônio de Figueiredo ${ }^{1}$

Marcus Vinicius Farbelow ${ }^{2}$

\begin{abstract}
The majority of current disciplines in Brazilian Higher Education is still rooted in the content-based-tradition concept, not being adapted to the expectations of interdisciplinary fields. The aim of this article is to deepen the reflection about the necessary education in contemporaneity, and to offer a real example analysis of the kind of education we understand as such. The approach's main characteristics were dialogicity, the procedural construction of content, the inclusion of the dimensions of research and extension in education, and the formative assessment. The application of the proposed approach in a socio-environmental discipline made it possible to verify the relevance of its foundations, as well as the possibility to act in real terms. We have concluded that the use of what we called "learning-research-action didactical approach" is possible in individual disciplines - these owning the potential to transform university courses' curricula gradually.
\end{abstract}

Keywords: University Extension; Action Research; Situated Learning; Dialogical Pedagogy.

\footnotetext{
${ }^{1}$ Biologist, Master and PhD in Ecology. Professor, Department of Environmental Sciences (DCAm) of the Universidade Federal de São Carlos (UFSCar), Brazil. E-mail: rodolfo@ufscar.br.

2 Social Scientist, Master in Agroecology and Rural Development. Technician in Geographic and Statistic Informations, Fundação Instituto Brasileiro de Geografia e Estatística (IBGE), Brasil. E-mail: marcus.farbelow@yahoo.com.br.

Revbea, São Paulo, V. 13, No 1: 108-123, 2018.
} 
Resumo: A maioria das disciplinas atuais na educação universitária brasileira ainda está enraizada no conceito de tradição baseada em conteúdo, não se adaptando às expectativas dos campos interdisciplinares. $O$ objetivo deste artigo é aprofundar a reflexão sobre a educação necessária na contemporaneidade e oferecer uma análise de exemplo real do tipo de educação que entendemos como tal. As principais características da abordagem foram a dialogicidade, a construção processual do conteúdo, a inclusão das dimensões da pesquisa e extensão na educação e a avaliação formativa. A aplicação da abordagem proposta em uma disciplina socioambiental nos permitiu verificar a relevância de seus fundamentos, bem como a possibilidade de atuar sobre o real. Concluímos que o uso do que chamamos de "abordagem didática ensino-pesquisa-ação" é possível em disciplinas individuais - possuindo a potencialidade de transformar os currículos dos cursos universitários gradualmente.

Palavras-chave: Extensão Universitária; Pesquisa-Ação; Aprendizagem Situada; Pedagogia Dialógica.

\section{Introduction}

The University is an institution that has arisen at the end of the Middle Age, at about the $12^{\text {th }}$ century in Europe (FILGUEIRAS, 2015). The education in this institution has become inspired by scholastics, which is a philosophictheological concept defined by Saint Thomas Aquinas (1227-1274), whose pedagogical method has as general characteristics: being formalistic, repetitive, redundant, and tending to dogmatism, based on the instructor's authority. Brazilian University has arisen much later; though our European colonizers had founded their first university in 1290 in Lisbon, they didn't have as a colonization policy to provide higher education (FÁVERO, 2006). The first university in Brazil only came at the beginning of the $20^{\text {th }}$ century, for 'the bourgeois' revolution advance in Brazil, from 1920 and 1930 decades onwards, transformed gradually educational matters in a national problem", according to Minto (2014, p. 167). Although we are many centuries far from this initial moment of formation of universities in Europe and Brazil, it is noticed that in most cases the Ratio Studiorum, a manual edited in 1599 by the Jesuits, and used in Brazilian schools since the beginning of the colonization (ALVES, 2005), is still used in the university disciplines, even unconsciously. The Ratio Studiorum states that the teacher has to: make an exposition about some subject, gather the arisen doubts, and elaborate fixation exercises for the students, to whom fits memorization for the assessment (HAMILTON, 2002).

Throughout the country's universities, it's often found a flagrant contradiction, which is embedded in the prevalent discursive context of abandonment of traditional education, in its majority understood as incompatible with the new necessities of the millennium. In fact, the classes pertaining to progressive pedagogies frequently take place ashamed in accordance to the

revista brasileira educação ambiental 
most sacred prescriptions of educational conservatism: upright, the master punctuates and teaches; seated and orderly, the disciples hear and learn. It is certain that students are not entirely privy to exerting the word. Nevertheless, this power does not belong to them; it is granted to them by the professor, only at certain moments, and under certain circumstances.

Anastasiou and Alves (2015, p. 11) advocate the necessity of "a new way of giving the university class", once "the used habitual ones do not meet institutional expectations, in relation to students, and professors".

Is it too difficult to put principles into practice in which one believes? Is it possible to reach an end employing means that deny it? Such issues must be the aim of appropriate reflexion. In this sense, our objective with the present article is to deepen the reflexion about the needed education on contemporaneity, and to offer the analysis of a real example of what we understand for such education. The work's specific objectives are:

1. To found theoretic-methodologically a progressive didactic-pedagogical approach for the undergraduate university disciplines;

2. To present an experience employing this approach in a socio-environmental undergraduate discipline;

3. To evaluate the results, and to indicate the potentiality of the experience to advance towards the inclusion of the research, and extension as intrinsic parts of a contextualized education, and that it makes sense for both students and professors.

\section{Theoretical-methodological foundation of the proposed didactical approach}

First of all, it is necessary to clarify what is understood as "progressive pedagogies". In this work, we consider progressive pedagogies those ones that go against - even in different manners and varied degrees - two of the founding principles of traditional education: (1) separation between learning and teaching; (2) separation between subject and object of knowledge.

\section{Dialectical pedagogy}

The dialectical pedagogy has as its core Karl Marx's (1818-1883) thoughts, constituted essentially of theoretical splits, and further developments of the praxis' concept. Despite being referred in many passages of the German philosopher's great work, the "Theses on Feuerbach" constitutes the praxis philosophy's epitome.

In "Theses", Marx vehemently rejects the artificial separation between theory and practice, between thought and action. As he affirms in his second thesis: 
The problem if to thought corresponds an objective truth is not a theory's problem, but a practical problem. It's in practice that the man has to demonstrate the truth, namely the reality and the force, the earthly character of his thought. The debate about reality or unreality of a thought isolated from the practice is a purely scholastic problem (MARX, n.d., p. 208).

The objective truth, so, does not correspond to the reiterated effort of abstract thought; it does, otherwise, to the result of a dialectical relationship between human being, and their environment - being them creator and product of the circumstances and the education. Therefore, the truth is the result of human praxis, apprehended necessarily as a transformative practice. In this way, it is not enough to interpret the world; it is about modifying it (thesis XI).

The education's dialectical conception implies, therefore, the assertion of the human being's transformative role in its different levels of action. In this sense, the ultimate reason for the educative process is not the reproduction of knowledge throughout time, such as it occurs in the traditional education, although the referred assets have uncontested relevance role. In the dialectical conception, the education has as its main objective to give to the real human being, immersed in a specific time-space framework, their own history's leading role. To this end, the educative process needs to be renewed: the educated is not a mere spectator, but agent of their own knowledge.

Moreover, it is necessary to assert that human beings' formation is a social task. It is not about an individual update of a preconceived, and preexisting human essence, as Gadotti (1997) affirms. The dialectical conception of education does not aim for the formation of leaders, good professionals, respectful and obedient citizens or, in a single expression, successful ones. On the contrary, it aims for the concrete liberation of a concrete human being, namely formed from multiple determinations, and not the result of a metaphysical given configuration a priori. Liberation of the human being as a collective being can only exist when all human beings are equally free, which cannot be mistaken by a bourgeois' freedom.

In this sense, the dialectical conception demands a political attitude, a position taken in favour of less favoured classes, continuously exploited, and subjugated by the big capital's powerful interests. It is about assuming major contradictions and injustices that reign in our society, and stand a position at the meekest side, whose liberation depends on the whole humanity's liberation.

In accordance to the dialectical current, the educative process must seek the collective human beings' emancipation, which derives fundamentally from work. Not from the prevalent alienated work within capitalist society, but from work as an essentially human characteristic, activity in which human beings might interact autonomously, seeing themselves in the fruit engendered by it. It is in the process of work that the human beings constitute themselves as such. 


\section{Dialogical pedagogy}

It is the pedagogy developed from Paulo Freire's (1921-1997) writings, mostly Pedagogy of the Oppressed and Education, the Practice of Freedom. It is well-known that the educator from Pernambuco (Brazil) was fed by marxist teachings, what explains the similarity between dialectic, and dialogic pedagogies.

One may say that the dialogue, as a means of human exclusive communication, has certain pre-requisites, and/or necessary conditions to its fulfilling, which are: (1) love to the world, to life, to human beings. Love that implies the adherence to the cause of the dominated and of the excluded, sufferers and ousted; (2) the recognition of human beings' incompleteness, a forever becoming; (3) the need for a fundamental humility. As an incomplete being, it is imperious to recognize the way in order "to learn and grow together". In this sense, it is equally necessary to know how to hear; (4) the conviction that the Truth, while essence to be revealed, does not exist; the truth will be built on the praxis, namely in the dialogic relation among men, always having reality as support, that also is altered. Nothing remains hermetic, immutable, and static. The knowledge process is intrinsically transformative, for it implies countless changes: on known subjects, on knowable objects, and on knowledge itself.

Some contemporary authors seek to associate the theory fundaments of Freire's dialogical pedagogy with unique characteristics of the new millennium. González and Díez-Palomar (2009), for instance, when analysing the rapid and intense transformations of the past two decades, commanded, and leveraged by the entitled technological revolution, state the occurrence of a "dialogical twist", which is broadly characterized by the proliferation of social actors/actresses with right to speak.

It cannot be put in check the relevance of the contemporary phenomenon of multiplication of legitimate voices, amplified by the dissemination of social media. However, it is necessary to avoid cacophony. To give voice to people that historically have not had it, this is a mandatory condition, but insufficient for the establishment of a fruitful and transformative dialogue. It is necessary the other conditions, some of which expressed above, those that are built socially and inter-subjectively. It is needed, therefore, that the word - the dialogue's base - be truthful, i.e. practical-reflexive:

The existence, because human, can't be mute, silent, neither in the opposite can it nurture itself from false words, but from truthful words, with which men transform the world. To exist, humanely, is to pronounce the world, is to modify it. The pronounced world, by its turn, returns problematizes to the pronouncing subjects, demanding from them a new pronouncing (FREIRE, 1987, p. 44). 


\section{Ensinagem (Learning)}

Teaching is a didactical approach that "involves mainly expositive classes, besides being often centred on the professor and guided by content, in other words, teaching is applied as a transmission, context in which the students are considered passive receptors of the transferred information" (UNESCO, 2016, p.46). In this conception, the acquisition of knowledge and behaviour goes one way: that of the knowledge-holder-teacher to the student (an empty repository waiting to be completed). According to Anastasiou (2015, p.19), in this view of education teaching "means to take note, retain in memory through studying, and receive information from it".

The processes of learning and teaching are interrelated in some approaches, such as that of constructivism, "that states learning as a process in which the student actively builds new ideas or concepts based on previous knowledge and/or experiences" (UNESCO, 2016, p.12). So, it is said that in teaching-learning process, having the hyphen the function of indicate that the two processes nurture mutually from each other.

On this path, the concept of ensinagem (here translated as "learning") arises, a neologism in Portuguese that aims to translate the process' dialectical characteristic (ANASTASIOU, 2015). The base of this concept is that the educative process occurs from the close interaction between students and professors, considering that teaching does not happen without learning, and vice-versa. The student and the professor get hold of the knowledge, becoming both critical and emancipated persons, for the knowledge and the comprehension that emerges from this integrates with the social actor's experienced reality. Therefore, the term learning applies:

To indicate a complex social practice realized between subjects - professor and student, encompassing not only the act of learning but the apprehending one, in a contractual process of deliberate and conscious partnership for the confrontation in the school knowledge's construction, due to actions realized in the classroom and outside of it (ANASTASIOU; ALVES, 2015, p.20).

Learning overcomes traditional education, since "it is proposed a processual dialectic unity, in which the professor's guiding role and the student's own activity get implemented in a two-way road" (ANASTASIOU, 2015, p. 20). 


\section{Action research}

Action research is a methodology that binds research and practice, having Kurt Lewin (1890-1947) as one of its first formulators. The knowledge and the comprehension of experienced reality by the researchers allow them to produce knowledge at the same time they intervene in reality. Therefore, action research settles on dialectical bases, once it perceives reality as a situated human construction that might be changed.

According to Thiollent (2008), the action research permits researchers to seek for existing problems in their life situations and go for their solutions. The methodology of action research has its application in basically all knowledge fields, including in the educational one. The professor can use this methodology to research aspects that makes sense to them in relation to teaching-learning, not depending on other professionals external to their relationship with disciplines, and students. "The professors, as men and women of educational practice, instead of being just the consumers of the research made by others, should transform their own classrooms in objects of research" (ENGEL, 2000, p. 183).

To El Andaloussi (2004, p.16), action research is more than one technique or methodology of field research, it is a "paradigm that has its own finalities, its own theory fundaments and its own characteristics". As a paradigm, we understand that there's the possibility for a new set of scientific activities to be developed in its scope. Kuhn (1998, p. 145) says: "during the revolutions, the scientists see new and different things when, using familiar tools, look at the same points already examined previously". So why not, at this moment, these possibilities of action research do not extend also to education, to integrate a didactical approach proposition?

\section{The proposed didactical approach}

The didactical approach proposed here falls in the scope of the dialectical and dialogical progressive pedagogies and has as its base the fundaments of learning, and action research.

The learning approach contributes with the proposition for it provides a horizontal relationship between professor and student, in which both are in a continuous process of learning, aiming possible synthesis on each moment of the development of the educative action in the scope of the discipline. The teamwork is a fundamental aspect of learning, and we used it in the approach proposed here. Another contribution of learning to the proposed approach is the employment of thoughtful portfolios, that positions "the student as responsible for their own learning process, the teacher being benefitted with the analysis of uniqueness, and peculiarities of each one's development" (ALVES, 2015, p.111). 
Action research contributes with this proposition for providing students actuation in concrete and practical situations, allowing that the teaching of the discipline does not become alienated, once it will be connected with a community's real life.

In this manner, the didactical approach here proposed presents the following characteristics:

1. the discipline's content is not approached through the professor's oral expositions, but it is built in a procedural manner along the discipline, through reading of renowned texts of the socio-environmental field, and the dialogue between professors and students about the themes;

2. also, the knowledge is built through practice, with students organized in small groups for the production of knowledge (research), and effective actuation in determined concrete reality (extension);

3. the research and the extension are planned, executed and assessed by students, through the obtained consensus in groups and with support of the professors;

4. the assessment of the discipline is formative, and takes place through three instruments: the reflexive portfolio about the theoretical-methodological basis, the presentation of developed work of research and extension, and the self-assessment.

\section{The application of the didactical approach}

We have applied the didactical approach in a discipline named "Environmental Education", which was offered in two situations: in an extended form along the academic semester, nocturnal period, and in a condensed form in one week of college vacation, full time. At the superior education institution in which we developed this work, the discipline Environmental Education is compulsory for the courses Degree in Biological Sciences, Degree in Physics, and Degree in Chemistry, in addition of being an optative for Bachelor's in Agroecology.

We organized the discipline around three learning nuclei: the first with the objective of mapping and diagnosing a determined socio-environmental reality; the second with the objective of producing knowledge about determined reality aspect; and the third with the objective of putting it into practice. We divided didactically each nucleus in four interlinked, and interdependent stage: (1) theoretical-methodological foundation; (2) planning; (3) concrete action; (4) analysis and assessment of the concrete action.

The first nucleus named "Diagnosing in Environmental Education" had as proposition dividing the students in smaller groups (permanent along the semester); beginning with an initial discussion about the guiding principles of a good socio-environmental diagnosis, this would form a particular picture of a 
local reality, the subsequential survey of its problems/deadlocks/difficulties, and its potentialities/references.

It is important to point out that the discussion referred above, as well as the supervening ones, did not occur in a granted context by the professors. In consonance with the progressive pedagogies prescriptions, the use of the word was equal. The students were stimulated to speak and to take a stand in face of the pointed texts, which they had read previously as asked in the extendedform-discipline. For the condensed-form-discipline, the reading of the texts was on group during the class. The individual reflexions about the read texts composed the portfolio of each student.

The last classes of the first nucleus were destined to planning (under the professors' supervision), execution (outside the classroom, naturally) and assessment of the concrete actions, and the set of the nucleus as such.

In this last moment, particularly, the professors had the opportunity to exchange experiences exposing their doubts and difficulties, besides presenting suggestions and constructive critics to the discipline's setting. Professor and trainee also proceeded to the assessment of their activities along the stage, underlining as central concern the low density of the involvement of students during the discussion of the theoretical texts in the extended discipline. In the condensed discipline, this was minimized, offered after the ending of extended disciplines - when the students had a pointed-out period for the text group reading.

Possibly due to the inertia and passivity engendered by the reiterated traditional classes along the school's track record, besides the intrinsic complexity of the selected texts, an attested fact by some students during the assessment, the student's engagement in the extended discipline occurred at an inferior level than that recommended in effectively-participative processes. For this reason, we modified the dynamics of the debates in this modality: in the two subsequent nuclei of learning, the group was split again in smaller groups (not necessarily identical to those that would carry out the intervention concrete actions), and teased by some questions that would be discussed internally in the group and, afterwards, shared with all the discipline's participants.

The second nucleus of learning, "Environmental Education Research", approached the necessary principles and the pre-requisites to the achievement of an action research in environmental education.

The planning, execution, and assessment stages were very important, while they underlined the inherent characteristics (and difficulties) to action research. In fact, the students reported different experiences that gave concreteness to an involvement needing other subjects of the research and, therefore, the evaluation of their knowledge and practice. Without this prerequisite, the action research loses its essential character, becoming a top-tobottom intervention process, authoritarian by definition and equally depleting.

It is worth registering that many projects turned towards the university itself, which, opposite of denoting a relative accommodation from the student, Revbea, São Paulo, V. 13, № 1: 108-123, 2018. 
represented the emergency of a new look into the academic community (something referred to by the students themselves during the assessment process). A look that proved to be more critical, willing to inquiring of certain practices, and procedures until then naturalized.

In this second nucleus, the students' involvement was significantly higher, which can be interpreted not only as the adjustment of the change done on the discussion process, but also the comprehension, and gradual acceptance by the students of a new discipline's proposition, whose core is the involvement itself.

The third nucleus, "To act in Environmental Education", has as a crucial point the concept of "popular environmental educator", someone primordially compromised with a "pedagogy of the sensitivity to Life" (SORRENTINO, 2014, p. 144) and, by extension, with the dialogical dimension of acting.

In the four constitutive stages of the nucleus, the students provided clues that they had captured the essence of the proposition, especially by presenting intervention participative projects based, as much as possible, on the capacity of hearing of the ones involved, avoiding imposing decisions that were foreign to them. It is certain that action research is not simple to put into practice. In a certain way, a "traditional" research, based on the separation between subject/object as postulates the Cartesian rationality is much easier to put into practice, as long as it is not transformative. Despite expressing some difficulties, it is possible to affirm that the students presented coherent and wellbased projects, many of which with a great transformative potential (though the effectiveness of this transformation depends, among other variables, on its temporal continuity).

There were twelve projects during the discipline (Table 1, next page), five of them having as theme "residues", four approaching "living beings" and three related to the "physical environment". Seven of these projects took place in the university itself and five in the city where the university campus is located. Most of the projects were developed at the university campus, mainly because the students were mostly concerned with the environmental problems they were experiencing, as well as that location is more favourable to develop a short-term project.

The end of the discipline was done with the presentation of the tasks done throughout the semester (extended modality)/and the week (condensed modality), submission of the thoughtful individual portfolios, and the application of a written assessment, much different from a conventional-considered test. Its main objective was to lead each of the students to a critical reflexion: about themselves, about the formed groups, class, professor, trainee, procedures, and their comprehension about the environmental education field. 
Table 1: Objects, objectives, and locations of the execution the class projects.

\begin{tabular}{|c|c|c|}
\hline $\begin{array}{l}\text { OBJECT OF } \\
\text { ACTION AND } \\
\text { RESEARCH }\end{array}$ & OBJECTIVE OF RESEARCH AND ACTION & $\begin{array}{l}\text { LOCATION } \\
\text { WHERE IT } \\
\text { WAS DONE }\end{array}$ \\
\hline Solid Residues & $\begin{array}{c}\text { Reduction in the use of reprographic copies in } \\
\text { disciplines }\end{array}$ & University \\
\hline Solid Residues & Selective garbage collection of cafeteria's residues & University \\
\hline Solid Residues & Selective garbage collection of campus' residues & University \\
\hline Organic residues & Reduction of food waste in the restaurant & University \\
\hline Chemical Residues & $\begin{array}{l}\text { Correct disposal of chemical residues during practical } \\
\text { laboratory classes }\end{array}$ & University \\
\hline Plant species & $\begin{array}{c}\text { Widening comprehension about the sugar cane } \\
\text { planting }\end{array}$ & University \\
\hline Trees & $\begin{array}{c}\text { Widening of the knowledge on trees by basic school } \\
\text { students }\end{array}$ & City \\
\hline Animals & $\begin{array}{c}\text { Widening of the knowledge about the wild birds by the } \\
\text { population }\end{array}$ & City \\
\hline Animals & Population's education about the bird "arara-canindé" & City \\
\hline $\begin{array}{c}\text { Physical } \\
\text { Environment }\end{array}$ & $\begin{array}{c}\text { Mapping of breeding places of the Aedes aegypt } \\
\text { mosquito }\end{array}$ & University \\
\hline $\begin{array}{l}\text { Physical } \\
\text { Environment }\end{array}$ & $\begin{array}{l}\text { Widening of comprehension of the socio-environmental } \\
\text { problems in urban micro river system }\end{array}$ & City \\
\hline $\begin{array}{l}\text { Physical } \\
\text { Environment }\end{array}$ & Increase of the diversity of plants in residential gardens & City \\
\hline
\end{tabular}

Source: authors.

\section{The applied didactical approach's evaluation}

In the extended modality, 54 students have evaluated the discipline, while in the condensed one, 33 students have done it.

The numbers show that in extended modality the proposed approach was well accepted: $81.5 \%$ of the students enjoyed it. However, more important than the quantitative aspect is the comprehension of the reasons that led the students to opt for such alternative.

The pointed reasons from those who liked it allow us to infer that the didactical approach employed, despite causing an initial strangeness, was widely understood in its fundaments (dialogue, collective knowledge construction, reflexion/action/reflexion).

Contrasting it with the traditional content-based-approach, the students identified important advantages, notably those related to the possibility of acting for real, transforming it. The education, according to the emphasized point of view by the students themselves, does not have to remain restrained to the mere transmission of accumulated knowledge, but to involve indisputably the formation of new intermediary knowledge in objective reality. 
Although they have liked it, the students recognize that the approach proposed constitutes a great challenge. Presumably, the correction of this statement was in the reasons pointed by those who liked it partially. The traditional approach, even when its limits are recognized, is entrenched in the students, almost all of them formed according to its prescriptions. A discipline that does not go back even occasionally to expositive classes, and to the seminars presented by students may seem little committed and serious, incompatible with the sternness and the sacralised environment characteristics of traditional classes.

Furthermore, the students pointed as limits of the proposed approach the effort to overcome the eventual superficiality of the arguments, and discussions disputed in the classroom. Even though all are co-responsible (participative perspective), it is undeniable that the professor (co-helped by the trainee), as an organizer and mediator, is the main responsible for the quality of the theoretical debate. That, therefore, is a welcome critic and that deserves reflexion. Nevertheless, it is necessary to underline that the textual analysis does not have an arbitrarily defined limit as starting point, but the formative assets of all of the involved, which means to affirm that the comprehension of the suggested texts constitutes a continuous process of approximation, from the previously available knowledge.

In relation to the condensed discipline, where $93.3 \%$ of the students spoke out having liked the proposed approach, the above-mentioned observations are worth almost ipsis litteris. We only would like to make two additions.

The first of them relates to the demand for more texts for reading and discussion. In fact, to find the balance point is not the easiest task. How many texts are necessary for the concretization of the proposed approach? The answer, we believe, one cannot answer in definitive, because there are the intermediary factors. It is important to be aware of the necessities and interests of the students, adjusting and adapting the proposal when needed.

The second refers to the difference of expectations existing between the students of extended, and condensed disciplines. We consider much probably to exist among the first ones a greater attachment to traditional classes. As for the second ones, for attending a discipline that escapes by its own characteristics from the "normality" of scholar life, it is probably that new approaches have more acceptance, especially when the students understand them (as they appear to have comprehended) its principles.

\section{Discussion}

We noted that there are few stories in Brazilian literature of experiences in which teaching presents dimensions of research and extension. Field classes are more common to be used, with very positive effects in learning (SILVA et al., 2017). Anastasiou and Alves (2015, p. 105) point that one of the strategies of ensinagem is the "usage of principles of education associated to that of the

revista brasileira educação ambiental 
research". The authors consider that this strategy is important as it promotes greater autonomy and responsibility for the students, training them for the intellectual work (ANASTASIOU; ALVES, 2015).

Branco et al. (2013) uses the action research in the student's formation in the nursery field on "drugs" thematic. These authors, therefore, apply the methodology of action research punctually in the discipline. They have concluded that the methodology provided the students to reach a criticalreflexive vision of the social problems, even about "drugs" (BRANCO et al., 2013).

Mendonça et al. (2015) used active methodologies of learning in a tutor's formation course for a half-on-site discipline, and the professor employed the action research approach to investigate the course's participants. The authors noted that the participants of the course presented dissatisfaction in relation to the traditional education and that "innovative processes of ensinagem (learning) were considered an important strategy of educational paradigm shift" (MENDONÇA et al., 2015, p. 373).

In the international scope, the literature has recently focused on innovative propositions for the usage in interdisciplinary areas, such as agroecology. In this sense, Lieblein et al. (2004) put agroecology students in the rural medium, in contact with the observed and lived phenomenon, so they could determine the theories that are necessary, and relevant. These authors utilized action research, defined by them as "learning through action and for action" (LIEBLEIN et al., 2010, p. 149).

Østergaard et al. (2010, p. 23) also pointed that the agroecology area "requires different ways of learning other than the conventional academic education". These authors suggest that the education occurs inside and outside universities, involving professors, students, and farmers. The authors report that they used learning based on phenomenology in the disciplines, i.e. the students develop abilities, competences, and values of their involvement in a phenomenon that need to comprehend and to act upon.

Francis et al. (2011) reported many cases of utilization of actioneducation to approach issues related to environment sustainability in disciplines of American, Swedish, and Norwegian universities. The theoreticalmethodological basis of these authors was the experiential learning envisioned by John Dewey, "that the key was learning by doing", utilizing the strategy of case study with open end ("open-ended case studies") (FRANCIS et al., 2011, p. 227). In this approach, students, professor and farmers unite around a real life situation, leading them to learning about the relevant questions to solve the focused problem. Some reported disciplines did not use textbooks, but published articles for the student's theory basis, and performed the action research to comprehend, and to act upon the faced reality (FRANCIS et al., 2011).

The didactical experiences related in the above studied literature point to important issues that also motivated us to propose, and to execute the Revbea, São Paulo, V. 13, № 1: 108-123, 2018. 
progressive didactical approach. The issues are the following: the formation of the students is not only professors' and university's role, but that of the whole community. Learning takes place also through contact with concrete real situations. The student needs to experience the incompleteness of the produced results by the use of scientific methodology, which are restrict and susceptible to future modification and the effective action in concrete reality is important and what is expected of university formation.

\section{Final considerations}

The proposed and applied didactical approach sought to allow biological and exact sciences areas' students, who are graduating as professors of these sciences, to comprehend that the "environment" does not exist displaced from human societies. Karl Marx understands human history as part of natural history (LEVINS; LEWONTIN, 1985, p. 253), considering that human societies and nature are in a dialectical relationship. Marx (2010, p. 107) affirms: "the society is the essential completed unity (vollendete) of man and nature, the true nature's resurrection, the finished naturalism of man and nature's humanism took to effect".

A future challenge that we realized from the development of this experience is that of the progressive didactical approaches used in undergraduate disciplines at universities to promote the overcoming of today's courses' curricula in which they belong. The Cartesian division of disciplines in the curriculum or matrix of the majority of university courses locks up the possibilities of interdisciplinary actuation of professors, whether on teaching or on research and extension. A hard reality to be overcome is certain, but we understand that this is an urgent necessity for the formation of the generations who are taking responsibility for the continuity of the human societies, and nature in our planet, whose self-knowledge skills, critical thinking about reality, leading-role on acting, non-aggressive communication, and setting of consensus are indispensable.

\section{Acknowledgments}

The authors thank Fábio Kusumi Otuka for English revision of the manuscript.

\section{References}

ALVES, G.L. Origens da escola moderna no Brasil: a contribuição jesuítica. Educação \& Sociedade, v. 26, n. 91, p. 617-635, 2005.

ALVES, L.P. Portfólios como instrumentos de avaliação dos processos de ensinagem. In: ANASTASIOU, L.G.C.; ALVES, L.P. (Eds.) Processos de ensinagem na universidade: pressupostos para as estratégias de trabalho em aula. Joinville: Univille, 2015, p. 109-129. 
ANASTASIOU, L.G.C. Ensinar, aprender, apreender e processos de ensinagem. In: ANASTASIOU, L.G.C.; ALVES, L.P. (Eds.) Processos de ensinagem na universidade: pressupostos para as estratégias de trabalho em aula. Joinville: Univille, 2015, p. 15-44.

ANASTASIOU, L.G.C.; ALVES, L.P. (Eds.). Processos de ensinagem na universidade: pressupostos para as estratégias de trabalho em aula. Joinville: Univille, 2015.

BRANCO, F.M.F.C.; MEDEIROS, J.M.; MONTEIRO, C.F.S. A pesquisa-ação na construção do conhecimento do acadêmico de enfermagem sobre 0 fenômeno das drogas. Revista de Enfermagem UFPE on line, v. 7, p. 985989, 2013.

EL ANDASOUSSI, K. Pesquisas-ações: ciências, desenvolvimento, democracia. São Carlos: EdUFSCar, 2004.

ENGEL, G.I. Pesquisa-ação. Educar em Revista, n. 16, p. 181-191, 2000.

FÁVERO, M.L.A. A universidade no Brasil: das origens à reforma universitária de 1968. Educar, n. 28, p. 17-36, 2006.

FILGUEIRAS, C.A.L. Origens da química no Brasil. Campinas: Unicamp, 2015.

FRANCIS, C.A.; JORDAN, N.; PORTER, P.; BRELAND, T.A.; LIEBLEIN, G.; SALOMONSSON, L.; SRISKANDARAJAH, N.; WIEDENHOEFT, M.; DeHAAN, R.; BRADEN, I.; LANGER, V. Innovative education in agroecology: experiential learning for a sustainable agriculture. Critical Reviews in Plant Sciences, v. 30, n. 1-2, p. 226-237, 2011.

FREIRE, P. Pedagogia do oprimido. $17^{\text {a }}$ ed. Rio de Janeiro: Paz e Terra, 1987.

GADOTTI, M. História das idéias pedagógicas. São Paulo: Ática, 1997.

GONZÁLEZ, A.G.; DÍEZ-PALOMAR, J. Metodología comunicativa crítica: transformaciones y cambios en el $\mathrm{s}$. XXI. Revista Electrónica Teoría de la Educación, v. 10, n. 3, p. 103-118, 2009.

HAMILTON, D. O revivescimento da aprendizagem? Educação \& Sociedade, v. 23, n. 78, p. 187-198, 2002.

KUHN, T. A estrutura das revoluções científicas. São Paulo: Perspectiva, 1998.

LEVINS, R.; LEWONTIN, R. The dialectical biologist. Cambridge: Harvard University Press, 1985.

LIEBLEIN, G.; ØSTERGAARD, E.; FRANCIS, C. Becoming an agroecologist through action education. International Journal of Agricultural Sustainability, v. 2, n. 3, p. 147-153, 2004.

MARX, K. Manuscritos econômicos filosóficos. São Paulo: Boitempo, 2010. 
MARX, K. Teses sobre Feurbach. In: MARX, K.; ENGELS, F. Obras escolhidas, volume 3. São Paulo: Alfa-Ômega, s/d.

MENDONÇA, E.T.; COTTA, R.M.M.; LELIS, V.P.; CARVALHO JUNIOR, P.M. Paradigmas e tendências do ensino universitário: a metodologia da pesquisaação como estratégia de formação docente. Interface, v. 19, n. 53, p. 373-386, 2015.

MINTO, L.W. A educação da "miséria": particularidade capitalista e educação superior no Brasil. São Paulo: Outras Expressões, 2014.

ØSTERGAARD, E.; LIEBLEIN, G.; BRELAND, T.A.; FRANCIS, C. Students learning agroecology: phenomenon-based education for responsible action. Journal of Agricultural Education and Extension, v. 16, n. 1, p. 23-37, 2010.

SILVA, E.F.; PAVINATO, J.M.S.; SAVI, D.; AHLERT, A. Atividade de campo no ensino superior: um estudo de caso etnográfico. Revista Brasileira de Educação Ambiental, v. 12, n. 5, p. 26-40, 2017.

SORRENTINO, M. Educador ambiental popular. In: FERRARO JUNIOR, L.A. (Ed.) Encontros e caminhos: formação de educadoras(es) ambientais e coletivos educadores, vol. 3. Brasília: Ministério do Meio Ambiente, 2014, p. 143-153.

THIOLLENT, M. Metodologia da pesquisa-ação. São Paulo: Cortez, 2008.

UNESCO. Glossário de terminologia curricular. Brasília: UNESCO, 2016. 